\title{
Learning Acts and the Role of Digital Technology in Achieving Coherence among Them
}

\author{
Charles Crook, Colin Harrison, and Carmen Tomas \\ University of Nottingham, Nottingham, UK
}

\section{charles.crook@nottingham.ac.uk Colin.harrison@nottingham.ac.uk carmen.tomas@ntu.ac.uk}

\begin{abstract}
An argument is made against singular conceptions of learning and in favour of a more practice orientation that embraces 'acts of learning' and presents learning as mediated interaction. The present paper explores this through fieldwork in secondary school classrooms in which new digital technology is observed in its meditational role for the orchestration of such acts. Orchestration is identified in terms of how it brings about conditions of learning 'coherence' - whereby meaning is rendered more solid through the coordination of learning acts within individual lessons, along with the effective coordination of acts across episodes and sites of learning and, finally, the creating of a stronger community dimension to learning through linking together different stakeholders in the learning practice.
\end{abstract}

Keywords: learning, technology, coherence, education

The full text of this paper is not yet available

\section{Biography}

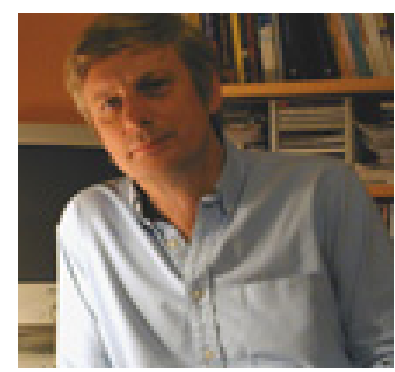

Charles Crook is Reader in ICT and Education at the University of Nottingham. He has a doctorate in experimental psychology from Cambridge University, has been a Research Fellow at Brown and Strathclyde Universities, a lecturer in Psychology at Durham and a Reader in Psychology at Loughborough Universities. His main interest is in the psychology of human development, with special concern for young people's use of new technologies. He has published a number of papers developing a cultural psychological approach to education and developmental psychology. He wrote one of the early

books on what has become known as "computer supported collaborative learning" and has pub-

Material published as part of this publication, either on-line or in print, is copyrighted by the Informing Science Institute. Permission to make digital or paper copy of part or all of these works for personal or classroom use is granted without fee provided that the copies are not made or distributed for profit or commercial advantage AND that copies 1) bear this notice in full and 2) give the full citation on the first page. It is permissible to abstract these works so long as credit is given. To copy in all other cases or to republish or to post on a server or to redistribute to lists requires specific permission and payment of a fee. Contact Publisher@InformingScience.org to request redistribution permission. lished empirical papers in most of the major journals of developmental psychology. He is currently editor of the Journal of Computer Assisted Learning. He takes an active part in disciplinary matters and is currently Chief Examiner of the British Psychological Society Qualifying Examination 